\title{
Reforming South Africa's procedures for granting patents to improve medicine access
}

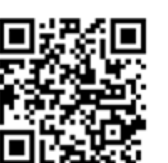

Led by the Department of Trade and Industry (DTI), South Africa (SA) is undergoing a process of reviewing and amending national laws governing the protection of intellectual property (IP). This process has the potential to remedy significant shortcomings in the current legislation that allow for the granting of an excessive number of patents, and evergreening of monopoly periods, at the expense of medicine access.

As a member of the World Trade Organization, SA is required to uphold minimum standards of IP protection as defined by the international Agreement on Trade Related Aspects of Intellectual Property Rights (the 'TRIPS' agreement). The TRIPS agreement requires SA to grant 20 years of patent protection on products and processes that meet SA's patentability criteria. These criteria are the standards of novelty, innovativeness and industrial applicability required to receive a patent. ${ }^{[1]}$

A key shortcoming of SA's current IP system is that the majority of patents granted fail to meet the country's patentability criteria. ${ }^{[2]}$ Patents that do not meet the country's patentability criteria are granted as a result of the depository system used for granting patents in the country without examination of their merits. ${ }^{[2-4]}$

In observing their TRIPS obligations, countries may use depository or examination systems for granting patents. ${ }^{[3-5]}$ In countries with depository systems, patent applicants are simply required to file the correct forms and pay the requisite fees in order to receive a patent. In other words, nobody checks patent applications to ensure that patentability criteria are met prior to the granting of patents. Conversely, under examination systems, the merits of a patent application are reviewed and applicants must demonstrate that patentability criteria have been met in order to receive monopoly protection. ${ }^{[3,4]}$

Given the lack of examination in SA, many patents are granted in this country that are rejected by countries and regions - including Brazil, the USA and the European Union (EU) - that have examination systems in place. ${ }^{[4,6]}$

A comparative analysis showed that SA granted $66 \%$ more pharmaceutical patents than the USA and the EU on identical patent applications filed between 2000 and 2002. ${ }^{[6]}$ Another study demonstrated that SA granted 2442 pharmaceutical patents in 2008 alone, while in comparison, Brazil granted only 278 in the 6 years between 2003 and 2008. ${ }^{[4]}$

The ease with which pharmaceutical patents are granted in SA permits pharmaceutical companies to gain multiple, successive patents on individual medicines, extending their periods of monopoly protection beyond the 20 years required by the TRIPS agreement. This practice is commonly known as 'evergreening'.

The challenge of evergreening in SA was highlighted in recent litigation over patents held on the popular birth control pill containing drospirenone and ethinyl oestradiol, sold by pharmaceutical company Bayer as Yasmin. The initial 20-year period of patent protection on this medicine ended in 2010 in SA. However, secondary, evergreening patents prevented generic versions from being brought to the market at a $30 \%$ price reduction when the initial patent expired. The Supreme Court of Appeal in Bloemfontein upheld Bayer's secondary patent in 2014, which means that generic use may continue to be blocked until 2024. Generic versions are already available in the USA and countries in Europe following rejection of Bayer's secondary patents in these countries. ${ }^{[7]}$
The hepatitis B medicine entecavir, marketed by Bristol-Myers Squibb in SA as Baraclude, further demonstrates the challenge of evergreening. The initial patent on this medicine expired in 2011, but secondary patents could prevent use of generic equivalents until 2026. Given the high local cost of Baraclude - between ZAR4 700 and ZAR5 500 per month for a hepatitis B patient - entecavir is not currently provided in the public sector. Yet generic equivalents are available outside SA at one-tenth of the price charged by the patent holder. ${ }^{[7]}$

Similarly, generic versions of aripiprazole (marketed in SA as Abilify), used to treat depression and bipolar disorder, are now available in the USA, yet secondary patents may block availability of generics in SA until 2033. SA consumers pay up to 35 times more for aripiprazole than those in India, where generic competition exists. ${ }^{[7]}$

Excessive patenting and evergreening of monopoly periods prevents South Africans from accessing more affordable, generic versions of many medicines, despite their widespread use and availability in other parts of the world. To address this challenge, SA must amend its laws and procedures for examining applications and granting patents.

Encouragingly, the DTI is currently undertaking a process of reviewing and amending SA's IP legislation. During 2013, the DTI released a Draft National Policy on Intellectual Property for public comment that contained commitments to pro-public health reform. According to the DTI, the finalised policy will be adopted this year, after which bills to amend IP legislation will be brought before Parliament.

The Fix the Patent Laws coalition has called on the DTI to urgently release a finalised policy recommending key reforms to curb evergreening and improve medicine access. The Fix the Patent Laws coalition comprises 15 health organisations in SA that represent patients seeking treatment and care in the realms of HIV, tuberculosis, sexual and reproductive health, cancer, mental health conditions, diabetes and other non-communicable diseases.

The reforms recommended by the Fix the Patent Laws coalition include, among others, setting stricter patent standards and requiring examination of pharmaceutical patent applications.

Under the TRIPS agreement, SA has the flexibility to set stricter patentability criteria that explicitly restrict patent evergreening. TRIPS-compliant countries - India, Argentina and the Philippines have adopted legislation or patent examination guidelines that limit or prevent patenting of new formulations (new dosages, combinations or forms (i.e. isomers, salts or polymorphs) of existing medicines) and new uses (new clinical uses of medicines other than those for which they are already registered or sold), except in very limited circumstances. Brazil is currently considering legislation to restrict these types of patents. In amending its patent legislation, SA should adopt similarly strict criteria to ensure that only truly innovative compounds and processes are granted monopoly protection.

In addition to setting stricter patentability criteria, SA must amend its system for granting patents to ensure that only patents meeting patentability criteria are granted. To do this, the country must replace its depository system with an examination system. In order to implement patent examination, SA will have to overcome capacity challenges.

The feasibility of an examination system in SA is currently the subject of rigorous debate. ${ }^{[8]}$ Discussions have centred largely on 
the human resource requirements for implementing examination, and whether SA can attract and hire sufficient numbers of qualified examiners. Patent examiners often have advanced degrees in their fields, and must have sufficient technical knowledge to judge the merits of a patent application. During 2013, the Indian Patents Office reported that 337 patent examiners were employed in the country. ${ }^{[5]}$

Attracting and hiring sufficient patent examiners will be a hurdle to implementing examination in SA. However, there are different approaches and models that could be pursued. ${ }^{[1,3]}$

\section{A partial or phased approach}

A partial or phased approach would initially focus on implementing examination for a few key sectors. This would reduce the number of examiners that the country would initially need to hire and train, allowing for capacity building over time. A partial or phased-in approach should initially focus on implementing examination for sectors that impact on government's ability to achieve its constitutional obligations - such as realising the right to health. ${ }^{[1,3]}$

\section{A collaborative approach}

A collaborative approach would allow SA to share the workload of examination with the patent offices of other countries or regions. If SA were to draw on decisions from other patent offices, many applications could be rejected automatically. However, in pursuing such an approach, careful consideration would have to be paid as to which patent offices ought to be selected for collaboration, taking into account that country and regional IP priorities and patentability criteria frequently differ. A rational approach would be for SA to collaborate with patents offices with comparable patentability criteria and adequate capacity for examination, in countries with similar socioeconomic backgrounds. ${ }^{[3]}$

\section{An opposition approach}

Patent opposition procedures are commonly used in many TRIPScompliant developed, and developing, country patent offices with examination systems in place.

An opposition approach would allow the SA Patents Office to draw on expertise from third parties operating in industry and civil society in determining whether patents should be granted. An opposition approach would require patent law reform to allow third parties (such as competing companies or NGOs) to comment on the validity of patents prior to and/or shortly after they are granted. This approach should be adopted together with a phased and/or collaborative approach.

For an opposition approach to work, information regarding pending, or recently granted, patents must be made publicly available. Additionally, third parties must be allowed to submit evidence to the SA Patents Office when patentability criteria have not been met during a designated time frame. ${ }^{[1,3]}$

\section{Conclusion}

While capacity challenges are a concern in implementing patent examination, given the negative impact of abusive patenting on medicines access, they should be assessed and dealt with accordingly. Implementing an opposition approach together with a partial/phased-in approach and/or a collaborative approach - or a combination of all these approaches - can assist SA in overcoming capacity constraints.

Currently, the only way for third parties to oppose the granting of patents in SA is through undertaking lengthy and expensive judicial challenges - despite the fact that patents are granted without ever assessing whether or not patentability criteria have been met. ${ }^{[1]}$
Frankly, SA's market is too small for most generic companies to bear the risk and cost of such a judicial challenge.

Adopting stricter patentability criteria, and implementing patent examination in SA, would significantly reduce the number of patents granted. Granting fewer patents will, in turn, facilitate generic competition, lower medicine prices, and ensure increased access to medicines for individuals who are currently unable to afford the treatments that they need, and for the government in its procurement of medicines for the public sector.

Endorsed by: Organisations (in alphabetical order): AIDS and Rights Alliance of Southern Africa; Association of Clinical Endocrinologists of South Africa; BreastSens; Cancer Association of South Africa; CanSurvive; Cape Mental Health; Centre for Diabetes \& Endocrinology; Diabetes South Africa; Diamond Life Impact Projects; Epilepsy South Africa; Marie Stopes South Africa; Médecins Sans Frontières Khayelitsha HIV/TB Project; Médecins Sans Frontières South Africa; National Association of Pharmaceutical Manufactures; Paediatric Neurology and Neurodevelopment Association of Southern Africa; Patient Health Alliance of Non-Governmental Organisations; People Living With Cancer; Rural Health Advocacy Project; Schizophrenia \& Bipolar Disorders Alliance; SECTION27; Society for Endocrinology, Metabolism and Diabetes of South Africa; South African Depression and Anxiety Group; South African Federation for Mental Health; Southern African HIV Clinicians Association; South African Medical Association (SAMA); South African Non-Communicable Diseases Alliance; Stop Stock Outs; TB Proof; Treatment Action Campaign; and the University of Cape Town's School of Public Health and Family Medicine. Individuals (in alphabetical order): Kwanele Asante-Shwonge, lawyer and African cancer equity activist, SA; Dr Elizabeth Augustine, City of Cape Town, SA; Prof. Brook K Baker, Northeastern University School of Law, Honorary Research Fellow at the University of KwaZulu-Natal, SA, Senior Policy Analyst at Health Gap, NGOs Alternate Board Member UNITAID; Dr Helen Cox, senior researcher, Division of Medical Microbiology, University of Cape Town (UCT); Prof. Larry A Distiller, specialist physician/endocrinologist, Principal Physician and Managing Director, Centre for Diabetes and Endocrinology, and Hon. Visiting Professor, Cardiff University School of Medicine, UK; Dr Kirsty Donald, Secretary, Paediatric Neurology and Neurodevelopment Association of Southern Africa; Laura Foster, Assistant Professor of Gender Studies, Indiana Maurer School of Law, Indiana University, USA, and visiting researcher, UCT; Veloshnee Govender, Lecturer, Health Economics Unit, UCT; Dr Mzukisi Grootboom, Chairman, SAMA; Ellen 't Hoen, Medicines Law and Policy, France; Prof. Mohamed Jeebhay, Head of Department and Director, School of Public Health and Family Medicine, UCT; Dr Bram de Jonge, Law \& Governance Group, Wageningen University, The Netherlands, and UCT IP Unit; Katie Kirk, intellectual property and legal consultant, USA; Jade Kouletakis, Lecturer, University of the Western Cape, Teaching and Research Assistant, UCT, and PhD student, UCT; Prof. Leslie London, Head, Division of Public Health Medicine, UCT; Prof. Diane McIntyre, Health Economics Unit, UCT; Prof. Graeme Meintjes, Department of Medicine, UCT; Mr Andrew Mews, Head of Mission for South Africa and Lesotho, MSF; Dr Caroline Ncube, Associate Professor/ Head, Department of Commercial Law, UCT; Dr Lonias Ndlovu, Senior Lecturer in Mercantile Law and Head of the Law Department, University of Zululand, SA; Lesley Odendal, TB/HIV activist and independent public health and communications consultant, SA; Marsha Orgill, researcher, 
Health Economics Unit, UCT; Dr Nesri Padayatchi, Deputy Director, Centre for the AIDS Programme of Research in South Africa; Dr Julian te Riele, Clinical Manager, Brooklyn Chest Hospital, Cape Town; Prof. Gail Scher, Chair, Paediatric Neurology and Neurodevelopment Association of Southern Africa; Morgan Scholtz, XDR-TB patient, Cape Town; Dr Tobias Schonwetter, Director, Intellectual Property Unit, UCT, and Regional Coordinator for Africa for the Creative Commons Corporation; Dr Edina Sinanovic, Director, Health Economics Unit, UCT; Dr Ronald van Toorn, Treasurer, Paediatric Neurology and Neurodevelopment Association of Southern Africa; Prof. Yousuf A Vawda, Academic Leader, Public Law, School of Law, University of KwaZulu-Natal; Lynne Wilkinson, project coordinator, MSF Khayelitsha Project, SA; and Prof. Jo Wilmshurst, PANDA SA committee board member, Head of Paediatric Neurology, Red Cross War Memorial Children's Hospital, Cape Town, and Director, African Paediatric Fellowship Program.

\section{Catherine Tomlinson, John Ashmore}

Médecins Sans Frontières Cape Town/Johannesburg, South Africa

\section{Anele Yawa}

Treatment Action Campaign, Cape Town, South Africa

\section{Julia Hill}

Médecins Sans Frontières Cape Town/Johannesburg, South Africa

Corresponding author: C Tomlinson (catherine.tomlinson@joburg.msf.org)

1. Park C, Prabhala A, Berger J. Using Law to Accelerate Treatment Access in South Africa: An Analysis or Patent, Competition and Medicines Law. New York: United Nations Development Programme, 2013. http://www.undp.org/content/undp/en/home/librarypage/hiv-aids/using-law-to-accelerate-treatmentaccess-in-south-africa.html (accessed 25 May 2015).

2. Pouris A, Pouris A. Patents and economic development in South Africa: Managing intellectual property rights. S Afr J Sci 2011;107(11/12), Art. \#355, 10 pages. [http:// dx.doi.org/10.4102/sajs. v107i11/12.355]

3. Ncube C. The draft national Intellectual Property Policy proposals for improving South Africa's patent registration system: A review. Journal of Intellectual Property Law \& Practice 2014;9(10:822-829. [http://dx.doi:10.1093/jiplp/jpu158]

4. Correa C. Pharmaceutical Innovation, Incremental Patenting and Compulsory Licensing. Research Paper 41. Geneva: South Centre, 2011. http://apps.who.int/medicinedocs/documents/s21395en/s21395en.pdf (accessed 28 May 2015)

5. Treatment Action Campaign, Médecins Sans Frontières, Research and Information System for Developing Countries. Why South Africa Should Examine Pharmaceutical Patents: How Legislative Reform Could Boost the Affordability and Accessibility of Medicines for South Africans. Johannesburg: Médecins Sans Frontières, 2013. http://www.msfaccess.org/content/why-south-africashould-examine-pharmaceutical-patents (accessed 27 May 2015).

6. Kapczynski A, Park C, Sampat B. South African Pharmaceutical Patenting: An Empirical Analysis. 2012. http://www.tac.org.za/sites/default/files/resources/Create\%20Resources/files/Sampat\%20presentation. pdf (accessed 25 May 2015)

7. Treatment Action Campaign, Médecins Sans Frontières. Accessing Oral Contraceptives, Hepatitis B Drugs and Medicines for Depression. Cape Town: Treatment Action Campaign, 2014. http://www. fixthepatentlaws.org/?p=911 (accessed 27 May 2015).

8. Daniels L. Comments Received on South Africass Process for New IP Policy. Geneva: Intellectual
8. 8. Daniels L. Comments Received on South Africas' Process for New IP Policy. Geneva: Intellectual
Property Watch, 2013. http://www.ip-watch.org/2013/11/18/comments-received-to-south-africasprocess-for-new-ip-policy/ (accessed 4 June 2015).

S Afr Med J 2015;105(9):741-743. DOI:10.7196/SAMJnew.8270 